\title{
Kepuasan Kerja Tenaga Medis pada Era Jaminan Kesehatan Nasional
}

\section{Work Satisfaction of Medical Personnel Era National Health Insurance}

\author{
Nur Fadhilah Arifin ${ }^{*}$, Syahrir A. Pasinringi ${ }^{2}$, Basir Palu ${ }^{3}$ \\ ${ }^{1}$ Fakultas Kedokteran Gigi, Universitas Muslim Indonesia \\ ${ }^{2}$ Departemen Administrasi Rumah Sakit, Fakultas Kesehatan Masyarakat, Unhas \\ ${ }^{3}$ Rumah Sakit Umum Wisata Universitas Indonesia Timur, Makassar \\ (*ila.6191@gmail.com)
}

\begin{abstract}
ABSTRAK
Tenaga medis sebagai ujung tombak pelayanan di rumah sakit sangat merasakan perubahan sistem pelayanan kesehatan pada era JKN yang menerapkan sistem kendali mutu dan kendali biaya. Penelitian bertujuan mengeksplorasi kepuasan kerja tenaga medis pada era Jaminan Kesehatan Nasional (JKN) di Rumah Sakit Umum Daerah Sinjai. Penelitian ini merupakan penelitian kualitatif deskriptif dengan pendekatan studi kasus. Informan penelitian adalah tenaga medis yang bertugas sebagai tenaga fungsional. Untuk memperoleh informasi tambahan sebagai pembanding, peneliti juga melakukan wawancara kepada Direktur, Kabid pelayanan dan keperawatan, Kepala sub-bagian keuangan dan petugas Sisrute di RSUD Sinjai. Data dikumpulkan melalui wawancara mendalam, observasi dan telaah dokumen. Hasil penelitian menunjukkan bahwa informan menyatakan sistem pelayanan kesehatan di era JKN baik, tetapi pelaksanaanannya belum berjalan sesuai yang diharapkan. Kerjasama BPJS dengan RSUD Sinjai baik dan cukup menguntungkan pihak RS, hanya sosialisasi regulasi dianggap lambat dan tidak konsisten serta penyelesaian masalahnya terkadang tidak ditindaklanjuti. Tenaga medis di RSUD Sinjai puas dengan tranparansi pembagian jasa medis, tetapi dalam besaran paket Ina CBGs dirasa masih dibawah standar, dan waktu pembayaran jasa medis terlambat.
\end{abstract}

Kata kunci : Kepuasan kerja, tenaga medis, JKN

ABSTRACT

Medical personnel as the spearhead of hospital services deeply feel the change in health care system in National Health Insurance (NHI) era that implements the system of quality control and cost control. The aim of the research was to explore the employee satisfaction of medical personnel in the era of the National Health Insurance in Regional Public Hospital of Sinjai. The research was a descriptive qualitative study with a case study approacch. The informants were medical personnel as functional personnel. To obtain additional information as comparison, the researcher also interviewed the director, the head of service and nursing unit, the head of financial sub-unit, and Sisrute officials in Regional Public Hospital of Sinjai. The data were obtained through indepth interview, observation and documentation. The result of the research indicate the service system in the era of National Health Insurance is good, but its implementation has not runas it is expected. The cooperation between BPJS and Regional Public Hospital of Sinjai is considered slow and inconsistent and sometimes the problem solving is not followed up. Medical personnel in Regional Public Hospital of Sinjai is satisfied with transparency of medical service division, but the number of Ina CBGs packages are still under the standar and time of payment of medical service is late.

Keywords : Work satisfaction, medical personnel, National Health Insurance 


\section{PENDAHULUAN}

Pada era Jaminan Kesehatan Nasional (JKN) sistem pelayanan kesehatan mengalami perubahan. BPJS Kesehatan menerapkan sistem managed care, yaitu suatu sistem pelayanan kesehatan dan pembiayaannya diselenggarakan dalam kerangka kendali mutu dan biaya. Perubahan mendasar pada sistem pembiayaan kesehatan akan mengubah pengelolaan pelayanan kesehatan. Perubahan sistem pelayanan kesehatan pada era JKN ini tentunya berdampak pada kepuasan kerja tenaga kesehatan di rumah sakit, terutama tenaga medis. ${ }^{1}$

Penelitian yang dilakukan oleh Kye Hyun sehubungan dengan pelaksanaan asuransi kesehatan nasional di Korea didapatkan hanya $6,4 \%$ dokter yang puas dan $28,3 \%$ masyarakat yang puas terhadap program ini, sisanya tidak puas. Dokter merasa tidak puas dengan sistem asuransi kesehatan nasional yang baru ini karena melemahkan otonomi dokter, meningkatkan beban kerja serta tanggung jawab dokter dalam pengembangan pembiayaan kesehatan, sehingga menurunkan kepuasan kerja mereka. ${ }^{2,3}$

Hasil penelitian Meutah LD mengenai kepuasan kerja dokter spesialis terhadap program JKN di RSUD Dr. Zainoel Abidin membuktikan bahwa $12,2 \%$ responden merasa sangat tidak puas, terdapat $35,4 \%$ responden merasa tidak puas. Terdapat $47,6 \%$ yang merasa puas, dan hanya $4,9 \%$ responden merasa sangat puas. Dari penelitian ini disimpulkan bahwa terdapat hubungan yang signifikan antara kepuasan dengan pengetahuan tentang INA CBgs, kondisi lingkungan kerja, remunerasi, transparansi, dan kebijakan rumah sakit ${ }^{4}$

Rumah Sakit Umum Daerah (RSUD) Sinjai merupakan satu-satunya rumah sakit di Kabupaten Sinjai yang menjadi rujukan utama seluruh fasilitas tingkat pertama di Kabupaten Sinjai untuk pelayanan tingkat lanjut program JKN. RSUD Sinjai bekerjasama dengan BPJS sejak Januari 2014. Setelah bekerjasama dengan BPJS, sistem penyelenggaraan pelayanan dan sistem pembiayaan di RSUD Sinjai mengalami perubahan. Perubahan ini terkait penyelenggaraan pelayanan kesehatan pada era JKN menganut sistem rujukan berjenjang, dari fasilitas kesehatan tingkat pertama hingga fasilitas kesehatan rujukan tingkat lanjutan kecuali dalam keadaan gawat darurat, pelayanan rujukan balik, dilakukan pembatasan dalam pemilihan tindakan medis yang diatur dalam clinical pathway, dan peresepan sesuai dengan formularium nasional. Sistem pembiayaan berubah dari sistem tarif per pelayanan (out of pocket) menjadi sistem paket INACBGs. ${ }^{5}$

Sistem rujukan berjenjang yang diterapkan di era JKN ternyata tidak mengurangi jumlah pasien yang berkunjung di RSUD Sinjai, bahkan terjadi peningkatan kunjungan pasien di RSUD Sinjai baik rawat jalan maupun rawat inap. Tercatat pasien BPJS pada tahun 2014 sebanyak 6014 pasien rawat jalan dan 2312 pasien rawat inap, sedangkan pada tahun 2015 pasien rawat jalan meningkat menjadi 15160 pasien dan pasien rawat inap meningkat 2912 pasien.

Penelitian ini penting dan strategis karena bertujuan mengeksplorasi kepuasan kerja tenaga medis di Era JKN. Tenaga medis merupakan sumber daya manusia yang sangat berperan dalam menjalankan pelayanan di rumah sakit. Dalam menjalankan regulasi BPJS, pihak BPJS memerlukan dokter sebagai mitra kerja untuk mendukung kelancaran program Jaminan Kesehatan Nasional ini. Kepuasan tenaga medis sangat penting dalam industri jasa yang merupakan faktor yang mempengaruhi kinerja sumber daya di rumah sakit dan hal tersebut berdampak pada kepuasan pasien, mutu pelayanan dan pendapatan rumah sakit. Oleh karena itu, penelitian ini dilakukan untuk memperoleh gambaran kepuasan kerja tenaga medis pada era JKN di RSUD Sinjai

\section{BAHAN DAN METODE}

Penelitian dilaksanakan di Rumah Sakit Umum Daerah Sinjai pada bulan Mei - Juli 2017. Metode penelitian yang digunakan dalam penelitian ini adalah metode penelitian kualitatif deskriptif dengan pendekatan studi kasus. Dalam penetapan informan kunci, peneliti memilih subjek penelitian berdasarkan prinsip kesesuaian, kecukupan dan kesediaan dengan memilih informan yang dianggap representatif dan memahami dengan baik substansi persoalan yang sedang diteliti dalam penelitian ini sehingga mampu memberikan informasi sebanyak mungkin. Adapun informan yang berhasil diwawancarai sebanyak 11 (sebelas) orang tenaga medis. Untuk memperoleh informasi tambahan ataupun pembanding, peneliti 
juga melakukan wawancara kepada Direktur RS, kepala Bidang Pelayanan Medik, Kepala Bidang Keuangan, Kepala Instalasi Farmasi, dan Perawat.

Data yang dikumpulkan pada penelitian diperoleh dari hasil wawancara mendalam dan observasi dengan menggunakan alat bantu tape recorder/handphone, alat tulis, pedoman wawancara, dan pedoman observasi, sedangkan data sekunder diperoleh dari hasil telaah dokumen. Data yang diperoleh dilapangan akan segera dianalisis melalui reduksi data. Mereduksi data berarti merangkum, memilih hal-hal yang pokok, memfokuskan pada hal-hal yang penting, mencari tema dan polanya. Dengan demikian data yang telah direduksi akan memberikan gambaran yang lebih jelas dan mempermudah peneliti melakukan pengumpulan data selanjutnya dan mencari bila diperlukan. Setelah data direduksi, selanjutnya adalah mendisplaykan (menyajikan) data. Langkah ketiga dalam analisis data kualitatif menurut Miles and Huberman adalah penarikan kesimpulan dan verifikasi. Untuk menjamin derajat kepercayaan data yang dikumpulkan digunakan metode triangulasi yaitu triangulasi sumber dan triangulasi metode. $^{6}$

\section{HASIL}

Berdasarkan hasil telaah dokumen, observasi, dan wawancara dengan informan diketahui bahwa masih banyak kasus-kasus non spesifik dirujuk ke RSUD Sinjai yang sebenarnya dapat ditangani di Fasilitas Kesehatan Tingkat Pertama (FKTP), tetapi karena ketidaktersediaan fasilitas, bahan medis dan atau obat sehingga harus dirujuk ke Rumah sakit Sinjai. Padahal tenaga medis di Fasilitas Kesehatan Tingkat Pertama (FKTP) telah cukup memadai.

'..tenaga dokter gigi di puskesmas untuk wilayah kabupaten sinjai telah terpenuhi, dan teman-teman telah hadir di puskesmas namun karena ketidaktersediaan alat ataupun bahan sehingga tekadang kasus-kasus yang sebenarnya bisa diselesaikan di puskesmas terpaksa harus dirujuk ke rumah sakit.."

(TA, 48 tahun)

Sistem Rujukan Terpadu (Sisrute) diakui in- forman cukup membantu dalam merujuk pasien. Aplikasi ini membantu tenaga medis untuk mengetahui sarana-prasarana, serta SDM pada rumah sakit tujuan, rumah sakit penerima juga dapat mengetahui keadaan pasien yang akan dikirim sehingga pihak rumah sakit penerima dapat mempersiapkan kebutuhan pasien, dan juga memberikan kejelasan rujukan pasien sehingga risiko terlantar dapat diminimalisir, hanya saja dalam pengaplikasiaanya Sisrute masih menghadapi beberapa masalah seperti waktu konfirmasi dari rumah sakit rujukan yang lama, gangguan jaringan internet, dan terkadang data pada Sisrute yang tidak diperbaharui. Berikut hasil wawancara informan :

“...jaringan wifi di rumah sakit sinjai ataupun di rumah sakit tempat merujuk yang kadang terganggu, selain itu tidak semua rumah sakit memiliki tenaga khusus yang standby mengoperasikan Sisrute sehingga komunikasi antar rumah sakit kadang menjadi terlambat.."

(NW, 40 tahun)

Berdasarkan hasil wawancara ditemukan bahwa untuk pasien UGD menghadapi administrasi yang rumit. Sebelumnya perjanjian rumah sakit dengan BPJS pasien emergency dapat langsung dibawa ke rumah sakit manapun, tetapi sekarang pihak rumah sakit harus menelpon rumah sakit rujukan mana yang bersedia menerima pasien. Selain itu, masalah yang sering dihadapi pada pelayanan sistem rujukan ketika RSUD Sinjai merujuk pasien ke fasilitas kesehatan selanjutnya adalah tidak ada kamar untuk pasien rujukan.

Berdasarkan hasil wawancara dengan informan adanya sistem rujuk balik tenaga medis merasa cukup terbantu, dokter yang merujuk dapat mengetahui perawatan yang diterima oleh pasien ditempat pasien dirujuk dan pengobatan selanjutnya yang harus dilakukan di faskes tempat merujuk, sehingga pengobatan terhadap pasien dapat berlanjut. Komunikasi antara dokter dengan fasilitas tingkat 1, 2 atau sebaliknya dapat berjalan dengan baik, seperti kutipan wawancara berikut ini :

"karena rujukan itu merupakan komunikasi antara dokter dengan fasilitas tingkat 1 , 2 atau sebaliknya, antara dokter dengan dokter yang merujuk itu ada komunikasi 
melalui sistem rujukan”

(AA, 54 tahun)

Pelayanan rujuk balik menurut informan penelitian belum terlaksana dengan maksimal. Kendala yang terjadi antara lain masalah ketidaktersediaan format rujuk balik, ketidakpatuhan dokter untuk mengisi format rujuk balik pasien, dan pasien tidak memberi lembar rujukan yang diberikan dari faskes yang merujuk. Ketidaktersediaan lembar rujuk balik membuat tenaga medis tidak punya waktu untuk menulis rujukan balik dengan baik, seperti kutipan wawancara berikut ini :

"..rujukan balik itu sebenarnya saya yang salah karena saya tidak punya waktu kadang menulis rujukan balik dengan baik, mau cuman kadang masih ada kerjaan yang lain lagi, jadi yah tidak sempat karena waktunya sempit,.."

(YA, 38 tahun)

Ketidaktersediaan obat pada FKTP lagilagi menjadi salah satu penyebab tidak berjalannya sistem rujukan balik ini. Beberapa pasien yang telah menerima pengobatan dan seharusnya bisa lanjut pengobatan di FKTP harus kembali dirawat lagi ke rumah sakit. Berikut ini kutipan wawancara dengan informan :

' ...Biasanya juga itu pasien dirujuk balik ke puskesmas, tetapi ternyata di puskesmas tidak ada obat, jadi yah kembali lagi dirawat di RS.."

(AFA, 37 tahun)

Hasil penelitian mengenai kepuasan tenaga medis terhadap penerapan clinical pathway, tenaga medis mengakui bahwa clinical pathway dibuat untuk kendali mutu dan kendali biaya pada pelayanan rumah sakit di era JKN sehingga beberapa clinical pathway yang dibuat lebih mengefesienkan dana atau mengurangi tindakan atau pelayanan yang bisa tidak dilakukan, seperti kutipan wawancara berikut ini :

"Clinical pathway yang dibuat simple sehingga terkadang malah dilanggar. Seperti penderita apendesitis yang meminta dilakukan USG, padahal USG tidak masuk dalam clinical pathway"

(MI, 40 tahun)

Dalam penyusunan clinical pathway di RUSD Sinjai menurut informan komite medik telah melibatkan semua profesi pemberi asuhan sehingga tidak ada pihak yang merasa terbatasi autonominya dalam memberi pelayanan. Berikut ini kutipan wawancara informan :

'..Tidak ada yang diberatkan dalam penerapan CP karena sudah melibatkan semua tenaga kesehatan, tidak hanya dokter."

(RAS, 40 tahun)

Kebijakan peresepan obat di RSUD Sinjai berdasarkan formularium rumah sakit yang mengacu pada formularium nasional. Dari hasil wawancara informan menyatakan bahwa masih ada beberapa obat yang dibutuhkan belum terdaftar dalam formularium nasional. Pengadaan obat yang diluar formularium nasional dibatasi oleh pihak rumah sakit, disesuaikan dengan tingkat urgensi kebutuhan dan anggaran di RSUD Sinjai.

"Ada obat yang tidak masuk di formularium nasional, tetapi saya minta untuk dimasukkan ke formularium rumah sakit, dan dipenuhi. Hanya saja jumlah obat diresepkan dibatasi"

(AFA, 37 tahun)

Dari hasil wawancara yang dilakukan ditemukan bahawa tidak ada masalah yang dihadapi tenaga medis dalam ketersediaan obat, bahan medis, maupun alat kesehatan. Dalam hal pengadaan pihak rumah sakit dinilai sudah cukup baik dan cepat tanggap, obat, alat atau bahan medis yang tidak ada akan segera dipenuhi oleh rumah sakit karena pihak rumah sakit memliki bentuk kerjasama dengan pihak luar seperti apotek luar jika ada obat yang tidak tersedia di rumah sakit, kecuali untuk bahan atau alat yang membutuhkan biaya besar prosesnya kadang membutuhkan waktu yang cukup lama.

“...apabila masuk di fornas tetapi obatnya habis di rumah sakit, dapat mengambil di apotik yang bekerja di rumah sakit atau pasien membeli ditempat lain dan nanti di- 
ganti”

(AR, 31 tahun)

Menurut informan kerjasama yang terjalin antara pihak RSUD Sinjai dengan BPJS Kesehatan cukup menguntungkan. Hal ini diungkapkan informan saat wawancara mendalam. Berikut kutipan wawancara dengan informan :

"Kerjasamanya kan lancar, karena pertama, setiap tahun itu ada namanya apakah $P K S$, setiap tahun itu diusulkan lagi kita, jadi itu ditandatangani langsung antara direktur dengan pihak BPJS"

(TA, 48 tahun)

Namun, ada perbedaan pendapat dari tenaga medis lain yang merasa kerjasama yang terjalin dengan BPJS justru merugikan. Resistensi ini datangnya dari tenaga medis yang kebanyakan kasusnya memerlukan tindakan operasi terhadap pasien. Berikut kutipan wawancara informan :

'Putus kontrak karena tidak saling menguntungkan, BPJS untung sedangkan tenaga kesehatan yang rugi ".

(ITJ,49 tahun)

Sosialisasi mengenai regulasi BPJS yang baru dirasa lambat bahkan terkadang tidak disosialisasikan, tetapi regulasi itu sudah berjalan. Berikut beberapa petikan wawancara terkait sosialisasi pelayanan JKN di RSUD Sinjai :

“......kadang-kadang lebih banyak memberikan sosialisasi pada saat nanti apabila ada masalah, lebih banyak tidak memberikan sosialisasi nanti ada komplain baru dia nyatakan ada aturan barunya, katanya yah dia berharap dari pihak rumah sakit yang mengupload dari internet karena pihak rumah sakit yang butuh.."

(AA, 54 tahun)

Sistem pembayaran pelayanan kesehatan bagi tenaga medis di RSUD menurut informan sangat transparan. Pembagiannya pun sudah ditentukan yaitu untuk fasilitas kesahatan $56 \%$, untuk jasa sebesar $44 \%$, dan pada saat pembagian jasa medis, tenaga medis diberikan kemudahan untuk mengakses persentase jasa yang didapatkan. Berikut kutipan wawancara informan :

"Transparan, sudah diatur bahkan kita sudah dibagikan buku yang sudah lengkap dengan persenannya, semua dokter dan semua tenaga kesehatan dibagikan"

(RAS, 40 tahun)

Tarif INA CBGs yang dianggap rendah menyebabkan besaran biaya yang dibutuhkan tidak sesuai dengan pelayanan yang harus diberikan oleh tenaga kesehatan. Nilai klaim yang diterima RS berdampak pada besaran jasa medis yang diterima oleh tenaga medis. Tarif Ina CBGs yang dianggap masih rendah dari standar yang diharapkan mengakibatkan ketidakpuasan dokter terhadap BPJS, seperti kutipan berikut ini :

“..Saya sudah berapa tahun selalu disubsidi RS, tetanus juga itu disubsidi, karena tetanus juga itu 3 juta ji lebih, kalau saya kasi tetagam sudah 3 juta, baru tetagamnya, belum Antibiotiknya, belum perawatannya bisa sampai 2 minggu 3 minggu. Pernah saya hitung hitung itu, pasienku itu bisa di subsidi sampai 167 juta selama 4 bulan. Banyak sekali."

(HK, 45 tahun)

Berdasarkan hasil wawancara dengan informan diketahui bahwa pembayaran jasa medis sering kali terlambat, menurut informan hal ini terjadi karena verifikator BPJS Kesehatan hanya berjumlah 1 orang. Jumlah ini dirasa masih kurang untuk melakukan verifikasi klaim pihak RSUD Sinjai.

"Sangat lambat.Rata-rata terlambat 3 bulan. Verifikasi dari BPJS lambat karena hanya 1 orang yang mengurus."

(AR, 31 tahun)

\section{PEMBAHASAN}

Beberapa tahun terakhir, pengorganisasian sistem kesehatan telah berubah secara signifikan. Untuk memperbaiki kinerja di sistem kesehatan, kebanyakan negara telah melakukan reformasi yang menghasilkan perbaikan besar-besaran, termasuk desentralisasi layanan kesehatan dan ad- 
ministrasi, otonomi untuk penyedia layanan publik, pemisahan badan pendanaan dan penyedia layanan, perluasan opsi pembiayaan kesehatan dan pengembangan sektor swasta keuntungan atau nirlaba. Reformasi sistem kesehatan di Indonesia dilakukan melalui program pembiayaan kesehatan secara nasional atau lebih dikenal dengan Jaminan Kesehatan Nasional. BPJS sebagai penyelanggara program JKN bekerjasama dengan RS. ${ }^{7}$

Kepuasan kerja tergantung pada apakah orang tersebut merasakan adanya suatu keadilan (equity) atau tidak atas apa yang telah dikerjakan dan apa yang dia dapatkan. Perasaan puas atau tidak puas ini diperoleh dengan cara membandingkan dirinya dengan orang lain dalam suatu organisasinya sendiri atau membandingkan yang dulu dia dapatkan dengan yang saat ini diperolehnya. ${ }^{8}$

Tenaga medis di RSUD Sinjai cukup puas terhadap penyelenggaraan sistem rujukan pada era JKN ini. Penyelenggaraan sistem rujukan dianggap belum sesuai dengan regulasi yang telah ditetapkan oleh BPJS, hal ini dapat dilihat pada rujukan yang tidak sesuai dengan indikasi rujukan yang diatur dalam Peraturan Menteri Kesehatan No.5 tahun 2014 tentang Panduan Praktek Klinis Bagi Dokter di Fasilitas Pelayanan Primer. Seharusnya diagnosa penyakit yang dirujuk haruslah penyakit-penyakit yang tidak dapat ditangani di FKTP yaitu kasus yang harus ditangani oleh speasialistik, tetapi karena ketidaktersediaan fasilitas, bahan medis dan atau obat sehingga harus dirujuk ke Rumah Sakit Sinjai. Hal ini membuat rujukan ke RSUD Sinjai meningkat yang dapat menambah beban kerja tenaga medis yang dapat mempengaruhi kepuasan kerjanya. ${ }^{9}$

Faktor yang mempengaruhi kepuasan kerja dokter adalah jumlah pasien. Semakin banyak pasien yang dilayani maka semakin besar waktu yang digunakan untuk praktik, semakin tidak ada waktu luang atau istirahat sehingga timbul ketidakpuasan terhadap kerjanya. Jumlah pasien yang dihadapi setiap minggu memiliki hubungan yang signifikan dengan kepuasan dokter dalam pelayanan kesehatan. Hal ini didukung dengan penelitian yang dilakukan di Iran tahun 2012 menjelaskan bahwa kepuasan kerja juga dipengaruhi oleh faktor intrinsik pekerjaan, diantanya adalah workload/beban kerja yang dihadapi. ${ }^{10,11}$

Data rumah sakit rujukan pada Sisrute ti- dak diperbaharui dan adanya gangguan jaringan internet pada saat melakukan rujukan membuat prosedur rujukan di era JKN dirasakan cukup ribet. Persoalan lainnya yang sering dihadapi pada pelayanan sistem rujukan ketika RSUD Sinjai merujuk pasien ke fasilitas kesehatan selanjut- nya adalah tidak ada kamar untuk pasien rujukan. Adanya pembatasan atau kuota jumlah tempat tidur yang disediakan bagi peserta JKN masih sering terdengar dibeberapa rumah sakit. Hal ini membuat masa rujukan menjadi lebih lama sehingga pasien dapat kehilangan periode emas untuk mendapatkan pengobatan. Kepuasan kerja tenaga medis dipengaruhi oleh kemudahan rujukan. Kemudahan sistem rujukan dapat menjadi indikator sebuah RS yang dikelolah dengan baik, membantu tenaga medis memberikan pelayanan pengobatan terbaik. ${ }^{12}$

Sistem rujuk balik merupakan salah satu komponen yang penting dalam penyelenggaraan pelayanan kesehatan di era JKN. Tenaga medis di RSUD Sinjai mengakui bahwa sistem pelayanan rujuk balik ini sangat baik, karena sangat membantu komunikasi antara tenaga medis di fasilitas kesehatan yang merujuk dan yang menerima rujukan. Dengan adanya rujukan balik ini membantu tenaga medis tempat pasien di rujuk karena dapat mengetahui keadaan pasien termasuk jenis perawatan dan pengobatan yang diberikan dokter kepada pasien tersebut sehingga lebih mudah melakukan pengobatan selanjutnya. ${ }^{13}$

Penelitian Eskandari, Abbaszadeh, \& Borhani menyatakan bahwa kualitas sistem rujukan merupakan salah satu faktor utama dalam menentukan proses perawatan kesehatan pada sebuah desa di Iran. Struktur sistem rujukan harus ditingkatkan dengan menciptakan koordinasi yang lebih baik antara tiga tingkatan sistem rujukan. Koordinasi yang lebih baik antara dokter yang merujuk dan spesialis meningkatkan kepuasan dokter. Perbaikan dalam proses rujukan bisa tercapai melalui komunikasi dan kolaborasi yang lebih baik antara Dokter perawatan primer dan spesialis. ${ }^{14,15}$

Masih adanya masalah ketidaktersediaan format rujuk balik sehingga tenaga medis tidak memberikan rujukan balik kepada pasien. Ketidakpatuhan dokter untuk mengisi format rujuk balik pun menjadi faktor penyebab utama tidak berjalannya pelayanan rujukan balik ini. Hasil pene- 
litian ini sejalan dengan penelitian yang dilakukan oleh Primasari yang menemukan bahwa ketentuan rujuk balik belum dilaksanakan dengan baik di RSUD Dr. Adjidarmo, hal ini disebabkan ketidakpahaman beberapa dokter tentang rujuk balik. ${ }^{16}$

Penerapan clinical pathway berpengaruh terhadap kepuasan kerja tenaga medis. Perencanaan pelayanan terpadu yang merangkum setiap langkah yang diberikan kepada pasien mulai masuk sampai keluar rumah sakit berdasarkan standar pelayanan medis, standar asuhan keperawatan dan standar pelayanan tenaga kesehatan secara detail telah ditentukan dalam clinical pathway. Tenaga medis di RSUD Sinjai tidak merasa terbatasi autonominya dengan penerapan clinical pathway pada era JKN ini karena dalam penyusunannya tenaga meds bersama pemberi asuhan lainnya yang terdiri atas perawat, bidan, farmasi, serta komite medik turut terlibat menyusun clinical pathway yang akan mereka jalani nantinya. ${ }^{17}$

Lodahl dan Kejner dalam Liao dan Lee mendefinisikan keterlibatan kerja adalah tentang cara seseorang mencerminkan dan menganggap bahwa pekerjaannya merupakan hal yang penting atau utama. Selain itu, keterlibatan kerja juga merupakan sejauh mana seseorang karyawan terlibat dalam pekerjaannya. Menurut Robbins dan Coulter mengatakan bahwa keterlibatan kerja adalah tingkat pengindenfikasian psikologis karyawan dengan perkerjaannya, secara aktif berpartisipasi dalam pekerjaannya, dan menganggap kinerjanya dalam pekerjaannya adalah penting untuk kebaikan dirinya sendiri. Karyawan yang memiliki keterlibatan kerja menganggap pekerjaan sebagai bagian yang paling penting dalam hidupnya dan benar-benar peduli dengan bidang pekerjaan yang mereka lakukan. Ini berarti bahwa dengan bekerja, karyawan dapat mengekspresikan diri dan menganggap bahwa pekerjaan merupakan aktivitas yang menjadi pusat kehidupan. ${ }^{18}$

Hal ini bertentangan dengan argumen Stoddard et al., bahwa dokter kehilangan professional otonominya di bawah managed care. Clinical autonomy dikompromikan di bawah managed care, seperti seringkali harus meminta persetujuan sebelum memulai perawatan, hanya meresepkan obat yang diotorisasi, mengikuti rencana pengobatan spesifik untuk penyakit tertentu. Bahkan dengan managed care, otonomi dokter terancam saat membuat keputusan berkenaan kondisi pekerjaannya, tertekan terhadap jadwalnya, termasuk clinical autonomy yang berpengaruh kuat terhadap kepuasan dokter pada era managed care. ${ }^{19,20}$

Pelaksanaan clinical pathway yang telah disusun kadang tidak sesuai dengan yang diharapkan, adanya varians-varians tertentu seperti kondisi perjalanan penyakit, penyakit penyerta atau komplikasi, maupun kesalahan medis yang menyebabkan penyimpangan langkah yang tidak sesuai dengan yang telah direncanakan dalam menangani pasien. Masalah lain yang dikemukakan oleh informan bahwa clinical pathway lebih fokus pada pengendalian biaya dengan tujuan agar rumah sakit tidak mengalami kerugian. Beberapa clinical pathway yang dibuat lebih mengefesienkan dana atau mengurangi tindakan atau pelayanan yang bisa tidak dilakukan. ${ }^{21}$ Tenaga medis dituntut untuk melengkapi catatan perkembangan pasien secara integrasi di rekam medik unuk dapat melakukan evaluasi terhadap pelaksanaan clinical pathway. Hal ini membuat beban administrasi dokter pun meningkat. Hal ini juga dapat mempengaruhi kepuasan kerja tenaga medis.

Pemberian obat bagi peserta BPJS Kesehatan mengacu pada Formularium Nasional (ForNas) untuk menjamin aksesibilitas keterjangkauan dan penggunaan obat secara nasional. RSUD Sinjai dalam meresepkan obat pada pasien berdasarkan formularium rumah sakit yang mengacu pada formularium nasional. Beberapa obat yang esensial belum terdaftar dalam formularium nasional menyebabkan ketidakpuasan bagi tenaga medis di RSUD sinjai. Beberapa tenaga medis juga mengeluhkan bahwa obat yang masuk dalam fornas terkadang tidak adekuat dalam penyembuhan pasien. Hal ini sesuai dengan penelitian ketidakpatuhan dokter spesialis menulis resep sesuai Fornas dikarenakan obat yang dibutuhkan tidak diakomodir dalam Fornas dan karena persepsi tentang manfaat dan mutu obat Fornas masih rendah..$^{22,23}$

Pengusulan kebutuhan obat pasien di era JKN yang tidak masuk dalam daftar Fornas di RSUD Sinjai diakomodir oleh Panitia Farmasi dan terapi, tetapi pengadaannya terbatas sesuai dengan ketersediaan dana. Oleh sebab itu, peresepan obat untuk pasien juga dibatasi. Dalam wawancara dengan beberapa tenaga medis ditemukan bahwa 
ketidakpuasan tenaga medis pada penyelenggaraan JKN salah satu penyebabnya adalah adanya pembatasan peresepan obat. Padahal salah satu kewenangan klinis dokter adalah membuat dan menuliskan resep tanpa intervensi pihak manapun.

Keterbatasan ketersediaan obat di era JKN masih menjadi masalah dibeberapa rumah sakit. Namun, tidak demikian yang terjadi di RSUD Sinjai, tenaga medis mengakui bahwa mereka puas atas ketersediaan obat di RSUD Sinjai, pihak farmasi dan manajemen sangat tanggap akan kebutuhan obat dan bahan medis yang dibutuhkan oleh tenaga medis. Hal ini bertentangan dengan penelitian yang dilakukan di rumah sakit Manna Kabupaten Bengkulu Selatan, ketidakpuasan kerja dokter spesialisis disebabkan oleh ketidaktersediaan fasilitas untuk penegakan diagnosa, obat-obatan serta bahan-bahan medis habis pakai yang terbatas dan penyediaannya terlambat. ${ }^{24}$

Kerjasama yang terjalin antara RSUD Sinjai dan BPJS Kesehatan menurut tenaga medis cukup baik dan menguntungkan. Kerjasasama yang baik ini berjalan sesuai dengan PKS (perjanjian kerjasama) yang disusun kedua belah pihak dan ditandatangani direktur RSUD Sinjai dan BPJS. Menurut teori yang dipaparkan oleh Gibson menyebutkan pekerjaan seseorang bukan hanya aktivitas-aktivitas yang nyata dan kasat mata, tetapi juga berupa interaksi dengan lingkungannya, baik rekan kerja, atasan, maupun bawahannya. ${ }^{8}$

Pelaksanaan kerjasama antara BPJS dan RSUD Sinjai yang terjalin baik, masih menghadapi beberapa masalah. Ketidakpuasan tenaga medis di RSUD Sinjai terkait sosialisasi mengenai regulasi BPJS yang baru dirasa lambat, dan tidak konsisten terhadap kesepakatan awal bahkan terkadang tidak disosialisasikan, tetapi regulasi itu sudah berjalan. Regulasi yang ada kadang disampaikan hanya secara lisan saja tidak ada bukti secara tertulis sehingga ketika ada masalah tenaga medis tidak memiliki dasar yang kuat.

Salah satu penyumbang faktor yang terbesar terjadinya ketidakpuasan adalah masalah komunikasi. Komunikasi yang lancar antar karyawan de-ngan pihak manajemen banyak dipakai alasan untuk menyukai pekerjaannya. Dalam hal ini adanya kesediaan pihak atasan untuk mau mendengar, memahami dan mengakui pendapat ataupun prestasi karyawannya sangat berperan dalam menimbulkan rasa puas terhadap kerja. Kebijakan perusahaan memberikan dampak pada kepuasan kerja karyawan. ${ }^{26}$

Tingkat kepuasaan pegawai kesehatan mengenai besarnya jasa pelayanan merupakan salah satu indikator sejauh mana keberhasilan dari pelayanan yang diberikan oleh pihak Badan Penyelenggara Jaminan Sosial kepada fasilitas kesehatan. Jadi, jasa pelayanan berpengaruh terhadap kepuasan dalam bekerja dan semakin besar jasa pelayanan yang diterima maka semakin puas pula seseorang tersebut dalam bekerja. Sebagian tenaga medis mengungkapkan bahwa pendapatan setelah JKN meningkat daripada sebelumnya. Beberapa tenaga medis mengeluhkan besaran jasa yang diterima di era JKN apabila dibandingkan dengan sistem pembayaran sebelum era JKN. Keluhan ini muncul dari tenaga medis yang umumnya banyak melakukan tindakan/operasi dalam melayani pasien. Tarif INA CBGs yang dianggap rendah apalagi bila dibandingkan saat fee for service menjadi faktor penyebab ketidakpuasan tenaga medis di era JKN. 4,27

Persepsi dokter terhadap pembagian jasa pelayanan berhubungan dengan kinerja secara signifikan dan cukup kuat. Aspek lain yang menyebabkan ketidakpuasan pemberi pelayanan terhadap jasa pelayanan yang berdampak pada penolakan adalah waktu pembayaran jasa pelayanan tidak jelas, tidak adanya transparansi dalam mekanisme pembagian dan penetapan indeks dan ketidaktahuan akan sistem pembagian karena dokter spesialis belum terlibat dalam perumusan sistem pembagian jasa pelayanan yang telah digunakan sebelumnya. ${ }^{28}$

Penentuan persentase pembagian jasa medis sudah transparan dan sudah sangat jelas, dalam penyusunan sistem pembayaran tenaga medis dan pihak rumah sakit, serta tenaga profesi lain yang bekerja di rumah sakit duduk bersama dan mencapai kesepakatan bersama dengan para petugasnya tentang pengaturan pembayaran jasa medis yang memuaskan semua pihak yang meliputi dokter, perawat dan staf lainnya dan pihak manajemen rumah sakit. Tenaga medis dapat tahu besaran jasa yang akan diterimanya. Adanya kesepakatan antara semua pihak akan memberikan kepastian bagi manajemen dan kepuasan bagi para petugasnya. Pada dasarnya seseorang bekerja mengharapkan 
imbalan yang sesuai dengan jenis pekerjaannya, apabila semakin terdapat kesesuaian maka kinerja akan semakin baik. Kompensasi yang proporsional akan memotivasi dan memuaskan karyawan, sedangkan kompensasi yang tidak proporsional akan menimbulkan keluhan, penurun prestasi, kepuasan kerja dan menurunkan moral pekerja.

Ketidakpuasan tenaga medis muncul terhadap keterlambatan pembayaran jasa medis karena masalah verifikasi yang lama karena verifikator BPJS hanya satu orang. Hal ini sesuai dengan penelitian yang dilakukan di RS Nene Malommo dan RSUD Kota Makassar mengenai kepuasan kerja dokter spesialis pada pelaksanaan JKN, pembayaran jasa medis yang sesuai dengan waktu dan besaran oleh dokter spesialis menimbulkan kepuasan bagi dokter spesialis. ${ }^{29}$

Berdasarkan teori kepuasan discrepancy yang diperkenalkan oleh Porter, kepuasan kerja seseorang diukur dengan menghitung selisih antara yang seharusnya dengan kenyataan yang dirasakan. Teori ini juga menjelaskan bahwa seseorang seseorang akan merasa puas dalam bekerja jika tidak ada perbedaan antara yang diinginkan dengan persepsinya atas kenyataan yang mereka terima, karena batas minimal kebutuhan telah dipenuhi. Apabila yang didapat lebih besar dari yang diinginkan maka orang akan menjadi lebih puas walaupun terdapat selisih, tetapi selish tersebut adalah selisih positif, dengan demikian berarti lebih puas atau sangat puas. Sebaliknya apabila yang didapat jauh lebih kecil berada dibawah standar minimum, akan terjadi perbedaan yang bersifat negatif, sehingga makin besar ketidakpuasan seseorang terhadap pekerjaanya. Apabila kondisi aktual yaitu meliputi kondisi fisik, sosial, psikis dan finansial dirasakan telah memadai dan telah dirasakan sesuai dengan persepsi pekerja, berarti mereka telah terpuaskan. Namun, apabila kondisi-kondisi aktual tersebut jauh berada di bawah standar yang diinginkan, maka mereka semakin kecewa, tidak mendapatkan kepuasan kerja. ${ }^{8}$

\section{KESIMPULAN DAN SARAN}

Secara umum tenaga medis merasa cukup puas terhadap sistem penyelenggaraan pelayanan kesehatan di Rumah Sakit Umum Daerah (RSUD) Sinjai Era JKN. Kerjasama BPJS dengan RSUD Sinjai di era JKN baik dan cukup menguntungkan pihak RS, hanya saja sosialisasi regulasi dianggap terlambat dan berubah-berubah serta penyelesaian masalahnya terkadang tidak ditindaklanjuti. Tenaga medis di RSUD Sinjai puas dengan tranparansi jasa medis, tetapi dalam besaran jasa medis dan ketepatan waktu pembayaran masih menjadi keluhan. Peneliti menyarankan ketersedian obat dan kelengkapan sarana-prasarana di FKTP lebih ditingkatkan, sehingga tenaga medis di FKTP dapat menegakkan diagnosa dan menyelesaikan kasus dengan baik untuk mengurangi rujukan kasuskasus non spesifik ke rumah sakit. Penyeragaman form rujuk balik dari FKTP, peningkatan kepatuhan tenaga medis dalam memberi dan melengkapi lembar rujukan balik, revisi Formularium Nasional dan tarif INA CBGs dengan melibatkan organisasi profesi, organisasi rumah sakit daerah (ARSADA), dan organisasi rumah sakit swasta (ARSSI). Sosialisasi regulasi baru dari BPJS dapat dilaksanakan sebelum regulasi berjalan. Menambah jumlah verivikator BPJS di RS sehingga memudahkan dalam verifikasi dan pembayaran jasa medis tepat waktu.

\section{DAFTAR PUSTAKA}

1. Baker Lc, Cantor Jc. Physician Satisfaction Under Managed Care. Health Aff. 1993;12(Suppl.):258-270. Doi:10.1377.

2. Tyssen R, Palmer Ks, Solberg Ib, Voltmer E, Frank E. Physicians' Perceptions of Quality Of Care, Professional Autonomy, and Job Satisfaction in Canada, Norway, And The United States. Bmc Health Serv Res. 2013;13(1):516. Doi:10.1186/1472-6963-13-516.

3. Kim Kh, Park Ec, Hahm M Il. The Gap Between Physicians and The Public in Satisfaction with The National Health Insurance System in Korea. J Korean Med Sci. 2012;27(6):579-585. Doi:10.3346/Jkms.2012.27.6.579.

4. Meutiah, Latifa Dara \& Saifuddin Ishak. Analisis Kepuasan Dokter Spesialis terhadap Program Jaminan Kesehatan Nasional (JKN) di Rumah Sakit Umum Daerah Dr. Zainoel Abidin Tahun 2014. J Kedokt Syiah Kumala. 2015;15:7-19.

5. Permenkes RI Nomor 71 Tahun 2013 tentang Pelayanan Kesehatan Pada Jaminan Kesehatan Nasional. Jakarta: Kementerian Kesehatan RI. 
6. Sugiyono. Metode Penelitian Kuantitatif Dan Kualitatif (7th Ed.). Vol 7th Ed. Bandung: Alfabeta.

7. Perrot J. Different Approaches to Contracting in Health Systems. Bull World Health Organ. 2006;84(11):859-866. Doi:10.2471/ Blt.06.034314.

8. Dugguh Si. Job Satisfaction Theories: Traceability to Employee Performance In Organizations. Iosr J Bus Manag Ver I. 2014;16(5):23197668.

9. Peraturan Menteri Kesehatan No.5 Tahun 2014.Tentang Panduan Praktek Klinis Bagi Dokter Di Fasilitas Pelayanan Primer. Jakarta : Kementerian Kesehatan RI.

10. Bovier P A, Perneger T V. Predictors of Work Satisfaction Among Physicians. Eur J Public Health. 2003;13(4):299-305.

11. Bagheri S, Kousha A, Janati A, Asghari-Jafarabadi M. Factors Influencing The Job Satisfaction of Health System Employees in Tabriz, Iran. Heal Promot Perspect. 2012;2(2):190196.

12. Grembowski D, Paschane D, Diehr P, Katon W, Martin D, Patrick Dl. Managed Care, Physician Job Satisfaction, And The Quality Of Primary Care. J Gen Intern Med. 2005;20(3):271277. Doi:10.1111/J.1525-1497.2005.32127.X.

13. Kemenkes RI. Buku Pegangan Sosialisasi Jaminan Kesehatan Nasional dalam Sistem Jaminan Sosial Nasional. Departemen Kesehatan RI. 2013:1-75. Doi: 10.1017/Cbo97811 07415324.004.

14. Eskandari M, Abbaszadeh A, Borhani F. Barriers of Referral System to Health Care Provision in Rural Societies In Iran. J Caring Sci. 2013;2(3):229-236.

15. Forrest Cb, Glade Gb, Baker Ae, Bocian A, Von Schrader S, Starfield B. Coordination of Specialty Referrals and Physician Satisfaction With Referral Care. Arch Pediatr Adolesc Med. 2000;154(5):499. Doi:10.1001/Archpedi.154.5.499.

16. Primasari Kl. Analisis Sistem Rujukan Jaminan Kesehatan Nasional RSUD. Dr. Adjidarmo Kabupaten Lebak. J Arsi. 2015;1(2):78-86.

17. Buchert Ar, Butler G A. Clinical Pathways. Driving High-Reliability and High-Value Care. Pediatr Clin North Am. 2016;63(2):317-
328. Doi:10.1016/J.Pcl.2015.12.005.

18. Saputra Aa, Yono Lh, Sito L, Irvianti D. Analisis Pengaruh Keterlibatan Kerja dan Kepuasan Kerja terhadap Organizational Citizen Behavior Di Pt Prima Graphia Digital. Binus Bus Rev. 2013;4(2):897-903.

19. Stoddard Jj, Hargraves Jl, Reed M, Vratil A. Managed Care, Professional Autonomy, and Income: Effects on Physician Career Satisfaction. J Gen Intern Med. 2001;16(10):675-684. Doi:10.1046/J.1525-1497.2001.01206.X.

20. Warren Mg, Weitz R, Kuhs S. The Impact of Managed Care on Physicians. 1999;24(2):4456.

21. Iroth Js. Dampak Penerapan Clinical Pathwayterhadap Biaya Perawatan Pasien Stroke Iskemik Akut di RS Bethesda Yogyakarta [Tesis]. Yogyakarta: Universitas Gadjah Mada; 2016.

22. Herti T. Kepatuhan Dokter Spesialis Terhadap Implementasi Formularium Nasional Di RSUD Dr. M. Yunus Bengkulu [Tesis]. Yogyakarta: Universitas Gadjah Mada, 2015.

23. Tanner Ae, Ranti L, Lolo Wa. Evaluasi Pelaksanaan Pelayanan Resep Obat Generik pada Pasien BPJS Rawat Jalan di RSUP . Prof . Dr. R . D . Kandou Manado Periode Januari-Juni 2014. Pharmacon. 2015;4(4):58-64.

24. Bina Ampera Bukit, Laksono Trisnantoro Am. Kepuasan Kerja Dokter Spesialis di Rumah Sakit Umum Daerah Manna Kabupaten Bengkulu Selatan Dengan Pendekatan Emic. J Manajamen Pelayanan Kesehatan. 2003;06.

25. Friedberg Mw, Chen Pg, Van Busum Kr, Et Al. Factors Affecting Physician Professional Satisfaction and Their Implications for Patient Care, Health Systems, And Health Policy.; 2013. Doi:10.1214/07-Ejs057.

26. Kairys J, Zebiene E, Šapoka V, Zokas I. Satisfaction with Organizational Aspects of Health Care Provision Among Lithuanian Physicians. Cent Eur J Public Health. 2008;16(1):29-33.

27. Sudita I N. Pengaruh Kepuasan Gaji, Kepuasan Kerja, dan Komitmen terhadap Turn Over Intention (Studi Kasus pada Bidan Praktek Swasta di Kabupaten Sleman). J Bisnis Dan Ekon. 2015;6(1):89-99.

28. Noprinaldi, Meliala A, Utarini A. Persepsi Pengaruh Sistem Pembagian Jasa Pelayanan Terhadap Kinerja Karyawan di Rumah Sakit 
Jiwa Madani. J Manaj Pelayanan Kesehat. 2006;09(02):65-71.

29. Diliana S A. Analisis Kepuasan Kerja Dokter Spesialis pada Pelaksanaan Jaminan Keseha- tan Nasional di RS Nene Mallomo Kabupaten Sidenreng Rappang dan RSUD Kota Makassar Tahun 2014. [Tesis]. Makassar: Universitas Hasanuddin, 2014 